\title{
A Study on the Comparison of Burnout Syndrome, Among Medical Doctors in the Restive Areas and Non-Restive Areas of the South Thailand Insurgency
}

Jarurin Pitanupong, M.D., Chonnakarn Jatchavala, M.D., M.Sc.

Department of Psychiatry, Faculty of Medicine, Prince of Songkla University, Hat Yai, Songkhla 90110, Thailand

Received 7 June 2018 • Revised 6 August 2018 • Accepted 9 August 2018 • Published online 5 October 2018

\section{Abstract:}

Objective: This study aims to compare burnout syndrome as well as the associated factors among doctors, who work at, secondary and tertiary-care hospitals either: in the restive areas of Thailand's southern insurgency, and the nonrestive areas of nearby provinces.

Material and Methods: This was a cross-sectional designed study, which was conducted in order to survey all doctors, who worked at hospitals, located in lower, southern Thailand from; January to April 2018. The questionnaire used; The Maslach Burnout Inventory (MBI) Thai version questionnaire. The data was analyzed by descriptive statistics. The factors associated with burnout syndrome were analyzed by using chi-square test and logistic regression.

Results: The total number of participants were; 245 medical doctors. Fifty-eight percent of them were females, whilst $42.0 \%$ were males, and most of them were single (50.2\%). The mean age of the participants was; 35.9 years, and $30.2 \%$ of them worked more than 40 hours per week. The total prevalence of Burnout syndrome among them was; 99.6\%, with the highest score found to be in the emotional exhaustion section. There were no differences in burnout syndrome between, those who worked in restive areas and those who worked in non-restive areas of Thailand's southern insurgency, grade point average (GPA), perceived sleep/rest quality and perceived work stress were related to emotional exhaustion, while types of specialty, work hour/week and family relationships were associated with depersonalization. The sample size was not adequate for the personal accomplishment part analysis.

Conclusion: Almost all medical doctors, who worked at either secondary or tertiary-care hospitals in the lower, southern areas of Thailand, suffered from burnout, only 1 physician did not. The factors associated to burnout syndrome are; work hours per week, GPA, type of specialty, perception of sleeping/rest quality, perception of having stress from work and family relationships.

Keywords: burnout, medical doctor, south Thailand insurgency

Contact: Jarurin Pitanupong, M.D.

Department of Psychiatry, Faculty of Medicine, Prince of Songkla University,

Hat Yai, Songkhla 90110, Thailand.

E-mail: pjarurin@medicine.psu.ac.th
J Health Sci Med Res 2018;36(4):277-289 DOI: http://dx.doi.org/10.31584/jhsmr.201825 www.jhsmr.org 


\section{Introduction}

The terminology of "burnout" was firstly used to describe the syndrome of exhaustion observed among mental health or human service professionals. ${ }^{1,2}$ It is a pathological syndrome that comprises of the condition of emotional exhaustion (EE), depersonalization (DP) and a decreased sense of personal accomplishment (PA). ${ }^{3}$ Burnout may be related to work overloading and involved in emotionally demanding contacts with recipients, such as; clients and patients. ${ }^{2,3}$

To date, both the mental and physical health of medical health practitioners are of concern, due to the hard working, nature of their professions, which may in turn, lead to "burnout syndrome" and mental maladaptation, with an emphasis on physician's morbidity. A review of existing studies indicated that the rates of mortality from; vascular disease, cirrhosis of the liver and traffic accidents were three times higher among physicians than the general population. ${ }^{4}$ Regarding the psychological modules, a previous. qualitative study found that some professionals showed emotional mismanagement due to the lack of a subjective recognition of affective experiences. Therefore, they considered themselves as inadequate for the performance of their work and values. At the same time, they were busy with helping others, but unable to remind themselves to ask for help. ${ }^{2}$

As we know, individuals suffering from burnout syndrome (BS) fail to adapt due to exhaustion, and the depletion of psychological resources needed to cope with the demands required while working with people. These causes an imbalance between excessive work demands and limited coping resources, that may lead to patients experiencing higher risk-adjusted 30-day mortality, and a failure-to-rescue rate..$^{5-7}$ Nurses are more likely to experience burnout and job dissatisfaction. ${ }^{8}$ In 2016, according to Thailand's Medical Council database, the number of active doctors stood at; 53,190, whereas the population was approximately $65,125,000 .^{9}$ In 2014 , the data showed that the average proportion of population per one doctor was 1,377, however half of all the nation's doctors worked in Bangkok. Therefore, the real proportion of population per one doctor in other provinces is much higher than that present in Bangkok, and this might cause work overload and exhaustion. ${ }^{10}$

In 2011, a study showed that nearly half of Thai psychiatrists $(44.7 \%)$ reported a moderate-to-high level of EE, whereas most of them had a low level of DP (82.9\%) and a high level of PA (79.0\%). These imply that there is a high burnout level in terms of EE among Thai psychiatrists, but only a few of them neglected or mistreated their patients. Furthermore, most of them still felt that they were capable of doing their jobs efficiently. ${ }^{11}$

In Thailand, since 2004, the insurgency in the South of Thailand along with the unrest caused by political conflict, has manifested itself as continuous and escalating violence in the 3 provinces of Pattani, Yala and Narathiwas (known in the Thai media as the 3 southern border provinces or SBP) as well as in some parts of the neighboring, Songkhla province. From 2004 to 2014, 14,701 incidents of violence have been officially reported. As a consequence, 6,297 people have been killed, with another 11,375 being injured in total. ${ }^{12}$ Because of this, the continuous insurgency is presented as a chronic, life threatening condition that may produce insecure feelings and burnout among physicians, who work in the 3 SBP hospitals. Previous studies, however, of BS have been limited to only psychiatrists. Therefore, the research on the prevalence, associating factors and association between $\mathrm{BS}$, the level of violence in restive areas among medical doctors, who work in government hospitals in the 3 SBP and the other 4 southern provinces of Thailand, may be helpful in the development of psychological support systems for public health organizations within this region. 


\section{Objective}

1. To assess the prevalence of BS and associated factors among doctors, at secondary and tertiary-care hospitals in the lower, southern areas of Thailand.

2. To compare BS between the restive areas afflicted by insurgency, and the non-restive nearby areas in the south of Thailand.

\section{Material and Methods}

\section{Ethical consideration}

This study was approved by the Ethics Committee of the Faculty of Medicine, Prince of Songkla University (REC: 60-262-03-1).

\section{Study design}

A cross-sectional study was conducted in order to survey the data of all medical doctors working at the hospitals in the 3 SBP of; Narathiwas, Pattani, Yala, and 4 other provinces in the lower, southern areas of Thailand, such as: Songkhla, Satun, Trang and Phatthalung, from January to April 2018.

\section{Population}

All medical doctors working at the hospitals in the 3 SBP, and 4 other provinces in the lower, south of Thailand. The estimated size of our target population was at least 320 medical doctors.

According to the Ministry of Public Health records, there are 1,285 physicians on duty. ${ }^{13}$

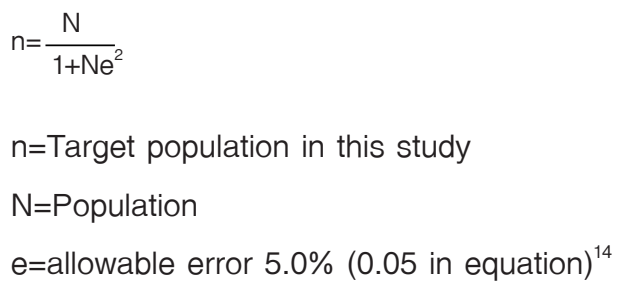

\section{Inclusion and exclusion criteria}

Inclusion criterion included: medical doctors, who have worked more than 1 year at either secondary, or tertiary hospitals of the 3 SBP, and 4 other provinces of the lower, south Thailand, 2018.

Exclusion criterion included; medical doctors who did not work at the hospital during the data collection period, or doctors who could not complete the questionnaire, or were not comfortable with participation in the study.

\section{Methodology}

The researchers asked the Public Health Ministry to address, and contact the relevant people at each secondary and tertiary-care hospitals in the lower south of Thailand. Therefore, we advocated for permission from the directors of each hospital. The research assistants, who worked as human resource officers at each of the secondary and tertiary-care hospital in lower southern Thailand, were asked to help us administer all of the sealed envelopes of the questionnaires to every medical doctor employed, at their institution, at that time. Consensus to participate in the study had to be individually agreed upon, and it was made clear that it was not a part of their routine work.

\section{Instruments}

The questionnaire comprised of 3 parts:

1. Demographic characteristics included; age, religious preference, hometown, parental marriage status, income, and underlying diseases.

2. Personal information and details regarding their medical career (18 questions approved by 3 Experts.)

3. The Maslach Burnout Inventory (MBI) Thai version questionnaire, comprised of 3 parts 
3.1 EE (Cronbach's alpha coefficient=0.9): never (score=0) to every day (score=6)

3.2 DP (Cronbach's alpha coefficient=0.7): never (score=0) to every day (score=6)

3.3 PA (Cronbach's alpha coefficient=0.7): every day (score $=0)$ to never $(\text { score }=6)^{15,16}$ (Table 1)

\section{Statistical analysis}

All questionnaires were checked for completeness. All data were performed using the $\mathrm{R}$ software package and were analyzed in order to describe the behavior of the sample, using the descriptive statistic method. The results were presented as; frequency, percentage, average and standard deviation. The associated factors of BS were analyzed using logistic regression.

\section{Results}

\section{Demographic data}

The total number of medical doctors participating in this study was; 245. Among the participants, there were 142 females (58.0\%) and 103 males (42.0\%). The mean age was $35.9 \pm 9.5$ years, with the mean cumulative GPA being 3.1 \pm 0.4 . Most of the participants were Buddhist $(80.0 \%)$, single $(50.2 \%)$ and having been doctors at a tertiary care hospital was 0-4 years (46.9\%). The mean duration of working at a tertiary care hospital was $7.9 \pm 8.3$ years, and the mean amount of working hours per week was $63.0 \pm 26.4$. Among the participants, they perceived adequate, or inadequate resting in nearly all equal data (48.6\% and $49.0 \%$ respectively), and also reported the type of stressors from working were; too high a work load (38.0\%), pressure from limited resources (24.4\%), an inappropriate income (11.3\%), job discordance from their own life style $(5.2 \%)$, and having problems with patients (5.2\%) (Table 2).

\section{Prevalence and comparison of BS between} restive and non-restive areas of Thailand's southern insurgency

Only 1 person had a zero score for all 3 parts of BS. Therefore the prevalence of BS among medical doctors in lower, southern Thailand was 99.6\%. BS comprised of conditions of EE, DP and decreased sense of PA. According to this survey, $42.1 \%$ and $36.3 \%$ of the participants had a low, or high a level of EE, with $62.0 \%$ of the participants having a low level of DP, whereas $96.7 \%$ of participants had a high level of PA. The mean score of EE, DP and PA were 22.2 $\pm 13.1,6.5 \pm 5.9,11.2 \pm 8.0$ respectively. The gender proportion of high EE was 36.9\% in the males and $35.9 \%$ in the females (Table 3). However, when comparing within working areas, we found there was no significant difference of burnout syndrome among medical doctors, who either worked between restive areas afflicted by insurgency, or non-restive areas of nearby provinces in southern Thailand (Table 4).

Table 1 Interpretation of The Maslach Burnout Inventory Thai version questionnaire

\begin{tabular}{|c|c|c|c|c|}
\hline \multirow{2}{*}{ Experience of burnout } & \multirow{2}{*}{ Item } & \multicolumn{3}{|c|}{ Level } \\
\hline & & Low & Moderate & High \\
\hline Emotional exhaustion & Item 1, 2, 3, 6, 8, 13, 14, 16, 20 & $0-16$ & $17-26$ & Up from 27 \\
\hline Depersonalization & Item 5, 10, 11, 15, 22 & $0-6$ & $7-12$ & Up from 13 \\
\hline Personal accomplishment & Item $4,7,9,12,17,18,19,21$ & Up from 39 & $32-38$ & $0-31$ \\
\hline
\end{tabular}


Table 2 Demographic characteristics $(n=245)$

\begin{tabular}{|c|c|}
\hline Demographic characteristics & Number (\%) \\
\hline \multicolumn{2}{|l|}{ Gender } \\
\hline Male & $103(42.0)$ \\
\hline Female & $142(58.0)$ \\
\hline \multicolumn{2}{|l|}{ Hometown } \\
\hline Songkhla & $52(21.2)$ \\
\hline 3 southern border provinces & $89(36.3)$ \\
\hline Other southern provinces & $72(29.4)$ \\
\hline Others & $31(12.7)$ \\
\hline No answer & $1(0.4)$ \\
\hline \multicolumn{2}{|l|}{ Religion } \\
\hline Buddhism & $196(80.0)$ \\
\hline Islam & $44(18.0)$ \\
\hline Christianity & $2(0.8)$ \\
\hline Others (no religion) & $3(1.2)$ \\
\hline \multicolumn{2}{|l|}{ Marital status } \\
\hline Single & $123(50.2)$ \\
\hline Married/couple & $115(46.9)$ \\
\hline Divorced/widow & $3(1.2)$ \\
\hline No answer & $4(1.6)$ \\
\hline \multicolumn{2}{|l|}{ Cumulative GPA } \\
\hline$<3.0$ & $59(24.1)$ \\
\hline $3.0-4.0$ & $162(66.1)$ \\
\hline No answer & $24(9.8)$ \\
\hline \multicolumn{2}{|l|}{ Hospital location } \\
\hline Trang & $58(23.7)$ \\
\hline Narathiwas & $50(20.4)$ \\
\hline Hatyai & $41(16.7)$ \\
\hline Pattani & $31(12.7)$ \\
\hline Yala & $27(11.0)$ \\
\hline Songkhla & $21(8.6)$ \\
\hline Satun & $17(6.9)$ \\
\hline \multicolumn{2}{|l|}{ Duration of work (year) } \\
\hline $0-4$ & $63(25.7)$ \\
\hline $5-10$ & $59(24.1)$ \\
\hline$>10$ & $119(48.6)$ \\
\hline No answer & $4(1.6)$ \\
\hline
\end{tabular}

Table 2 (continued)

\begin{tabular}{|c|c|}
\hline Demographic characteristics & Number (\%) \\
\hline \multicolumn{2}{|l|}{ Specialty } \\
\hline \multicolumn{2}{|l|}{ Major specialty } \\
\hline Pediatric & $25(10.2)$ \\
\hline Orthopedist & $12(4.9)$ \\
\hline Surgeon & $25(10.2)$ \\
\hline Gynecologist and obstetrician & $21(8.6)$ \\
\hline Medicine & $20(8.2)$ \\
\hline \multicolumn{2}{|l|}{ Minor specialty } \\
\hline Ophthalmologist & $12(4.9)$ \\
\hline Psychiatrist & $9(3.6)$ \\
\hline Oto-rhino-laryngologist & $13(5.3)$ \\
\hline Radiologist & $4(1.6)$ \\
\hline Anesthesiologist & $19(7.8)$ \\
\hline Emergency medicine physician & $4(1.6)$ \\
\hline Family physician & $19(7.8)$ \\
\hline General practitioner & $57(23.3)$ \\
\hline Other & $5(2.0)$ \\
\hline \multicolumn{2}{|l|}{ Work hour (per week) } \\
\hline$\leq 40$ & $74(30.2)$ \\
\hline $41-60$ & $62(25.3)$ \\
\hline $61-80$ & $36(14.7)$ \\
\hline$>80$ & $55(22.4)$ \\
\hline No answer & $18(7.3)$ \\
\hline \multicolumn{2}{|c|}{ Perceived quality of resting or sleeping } \\
\hline Adequate & $119(48.6)$ \\
\hline Not adequate & $120(49.0)$ \\
\hline Not sure & $1(0.4)$ \\
\hline No answer & $5(2.0)$ \\
\hline \multicolumn{2}{|l|}{ Perceived work stress } \\
\hline No & $30(12.2)$ \\
\hline Yes & $213(86.9)$ \\
\hline No answer & $2(0.8)$ \\
\hline \multicolumn{2}{|l|}{ Type of stress from working $(n=213)$} \\
\hline Too much work load & $81(38.0)$ \\
\hline Pressure from limited resource & $52(24.4)$ \\
\hline Inappropriate income & $24(11.3)$ \\
\hline Job discord from life style & $11(5.2)$ \\
\hline
\end{tabular}


Table 2 (continued)

\begin{tabular}{|c|c|}
\hline Demographic characteristics & Number $(\%)$ \\
\hline $\begin{array}{l}\text { Having problems with patients: } \\
\text { be sued }\end{array}$ & $11(5.2)$ \\
\hline Having problems with medical teams & $9(4.2)$ \\
\hline Other & $23(10.8)$ \\
\hline No answer & $2(0.9)$ \\
\hline \multicolumn{2}{|l|}{ History of physical illness } \\
\hline No & $183(74.7)$ \\
\hline Yes & $59(24.1)$ \\
\hline No answer & $3(1.2)$ \\
\hline \multicolumn{2}{|l|}{ History of psychiatric illness } \\
\hline No & $236(98.3)$ \\
\hline Yes & $4(1.6)$ \\
\hline No answer & $5(2.0)$ \\
\hline \multicolumn{2}{|l|}{ Family relationship } \\
\hline Excellent & $98(40.0)$ \\
\hline Good & $119(48.6)$ \\
\hline Fair & $26(10.6)$ \\
\hline No answer & $2(0.8)$ \\
\hline \multicolumn{2}{|l|}{ Initial reasons of working in the hospital } \\
\hline Near home & $135(55.1)$ \\
\hline Reimbursement education fund & $39(15.9)$ \\
\hline Follow couple or family & $20(8.2)$ \\
\hline Have a chance for study programming & $15(6.1)$ \\
\hline Others & $33(13.5)$ \\
\hline No answer & $3(1.2)$ \\
\hline
\end{tabular}

GPA=grade point average

\section{Associated factors related to burnout syndrome}

We compared between the groups of only EE and $\mathrm{DP}$, because of a lack in the sample size within the PA groups. Variables with $\mathrm{p}$-values, calculated from the univariate analysis that were lower than 0.2 were included in the multivariate analysis (Table 5). The results showed that, there were statistically significant associated factors related to burnout syndrome.
Cumulative GPA, type of specialist, perceived adequate, or inadequate resting and stress-perception from working were related to EE $(p-v a l u e<0.05)$. Additionally, cumulative GPA, type of specialist, amount of working hours per week, perception of resting and family relationship were related to DP ( $p$-value<0.05) (Table 5).

After analyzing and adjusting, doctors who had a higher cumulative GPA were at a 3.6 higher risk of EE, when compared with doctors who had lower cumulative GPA [95\% confidence interval $(\mathrm{Cl})=1.6-8.0]$. While the minor specialist doctors had a 2.6 greater chance of EE, when compared with doctors who were major specialist doctors (95\% Cl=1.3-5.2). However the doctor, who perceived inadequate resting or sleeping and having stressors from working, had an 8.4 and 5.9 greater risk of EE, when compared with doctors who perceived adequate resting and having no stressors related to working $(95 \% \mathrm{Cl}=4.0-17.7$ and $95 \% \mathrm{Cl}=1.6-22.5$ respectively) (Table 6).

The doctors who had a higher cumulative GPA had a 3.1 greater risk of DP, when compared with doctors who had a lower cumulative GPA (95\% Cl=1.3-7.2), and the minor specialist doctors had a 3.1 greater risk of DP, when compared with doctors who were major specialist doctors (95\% Cl=1.5-6.3). Doctors, who worked 41-60 and 61-80 hours per week, had a 4.3 and 6.1 greater risk of DP, when compared with doctors who worked less than 40 hours per week (95\% Cl=1.6-11.9 and 95\% Cl=1.9-19.3 respectively), whilst the doctors who worked more than 80 hours per week had a 3.3 greater risk of DP, when compared with doctors who worked less than 40 hours per week (95\% Cl=1.2-9.5). In addition to this, doctors who perceived inadequate resting, or sleeping as well as having fair family relationships had a 2.6 and 3.3 greater risk of DP, when compared with the doctors who perceived adequate resting and having excellent family relationships (95\% $\mathrm{Cl}=1.3-5.5$ and $95 \% \mathrm{Cl}=1.1-10.1$ respectively) (Table 6). 
Table 3 Experience of burnout syndrome $(n=245)$

\begin{tabular}{|c|c|c|c|}
\hline Experience of burnout & Number (\%) & $\begin{array}{l}\text { Male }(\%) \\
(n=103)\end{array}$ & $\begin{array}{l}\text { Female }(\%) \\
(n=142)\end{array}$ \\
\hline \multicolumn{4}{|l|}{ Emotional exhaustion } \\
\hline Low $(0-16)$ & $103(42.1)$ & $55(53.4)$ & $48(33.8)$ \\
\hline Moderate (17-26) & $52(21.2)$ & $10(9.7)$ & $42(29.6)$ \\
\hline High (up from 27) & $89(36.3)$ & $38(36.9)$ & $51(35.9)$ \\
\hline No answer & $1(0.4)$ & $0(0.0)$ & $1(0.7)$ \\
\hline \multicolumn{4}{|l|}{ Depersonalization } \\
\hline Low (0-6) & $152(62.0)$ & $61(59.2)$ & $91(64.1)$ \\
\hline Moderate (7-12) & $51(20.8)$ & $23(22.3)$ & $28(19.7)$ \\
\hline High (up from 13) & $41(16.7)$ & $19(18.4)$ & $22(15.5)$ \\
\hline No answer & $1(0.4)$ & $0(0.0)$ & $1(0.7)$ \\
\hline \multicolumn{4}{|l|}{ Personal Accomplishment } \\
\hline Low (up from 39) & $1(0.4)$ & $1(1.0)$ & $0(0.0)$ \\
\hline Moderate (32-38) & $4(1.6)$ & $2(1.9)$ & $2(1.4)$ \\
\hline High (0-31) & $237(96.7)$ & $98(95.1)$ & 139 (97.9) \\
\hline No answer & $3(1.2)$ & $2(1.9)$ & $1(0.7)$ \\
\hline
\end{tabular}

Table 4 Experience of burnout syndrome categorized by working area $(n=245)$

\begin{tabular}{|c|c|c|c|}
\hline Experience of burnout & $\begin{array}{l}\text { Non-restive (\%) } \\
(n=137)\end{array}$ & $\begin{array}{l}\text { Restive (\%) } \\
(n=108)\end{array}$ & $\begin{array}{l}\text { Chi-squared } \\
\text { P-value }\end{array}$ \\
\hline Emotional exhaustion & & & 0.167 \\
\hline Low $(0-16)$ & $60(44.1)$ & $43(39.8)$ & \\
\hline Moderate (17-26) & $23(16.9)$ & $29(26.9)$ & \\
\hline High (up from 27) & $53(39.0)$ & 36 (33.3) & \\
\hline Depersonalization & & & 0.901 \\
\hline Low $(0-6)$ & $86(63.2)$ & $66(61.1)$ & \\
\hline Moderate (7-12) & 27 (19.9) & $24(22.2)$ & \\
\hline High (up from 13) & $23(16.9)$ & $18(16.7)$ & \\
\hline Personal accomplishment & & & $0.794^{\mathrm{a}}$ \\
\hline Low (up from 39) & $1(0.7)$ & $0(0.0)$ & \\
\hline Moderate (32-38) & $3(2.2)$ & $1(0.9)$ & \\
\hline High (0-31) & $131(97.0)$ & $106(99.1)$ & \\
\hline
\end{tabular}

${ }^{a} \mathrm{p}$-value from Fisher's exact test 
Table 5 Results of univariate analysis: association between demographic variables and burnout syndrome: emotional exhaustion and depersonalization $(n=244)$

\begin{tabular}{|c|c|c|c|c|c|c|}
\hline \multirow[b]{2}{*}{$\begin{array}{l}\text { Demographic } \\
\text { characteristics }\end{array}$} & \multicolumn{2}{|c|}{ Emotional exhaustion } & \multirow[b]{2}{*}{$\begin{array}{l}\text { Chi- } \\
\text { squared } \\
\text { P-value }\end{array}$} & \multicolumn{2}{|c|}{ Depersonalization } & \multirow[b]{2}{*}{$\begin{array}{l}\text { Chi- } \\
\text { squared } \\
\text { P-value }\end{array}$} \\
\hline & $\begin{array}{l}\text { Low }(\%) \\
(n=103)\end{array}$ & $\begin{array}{l}\text { Moderate/ } \\
\text { high }(\%) \\
(n=141)\end{array}$ & & $\begin{array}{l}\text { Low (\%) } \\
(n=152)\end{array}$ & $\begin{array}{l}\text { Moderate/ } \\
\text { high }(\%) \\
(n=92)\end{array}$ & \\
\hline Gender & & & 0.004 & & & 0.476 \\
\hline Male & $55(53.4)$ & $48(34.0)$ & & $61(40.1)$ & $42(45.7)$ & \\
\hline Female & $48(46.6)$ & $93(66.0)$ & & 91 (59.9) & $50(54.3)$ & \\
\hline Age (year) & & & $<0.001$ & & & $<0.001$ \\
\hline$<30$ & $16(15.7)$ & $55(39.0)$ & & $23(15.2)$ & $48(52.2)$ & \\
\hline $30-40$ & $50(49.0)$ & $60(42.6)$ & & $79(52.3)$ & $31(33.7)$ & \\
\hline $41-60$ & $36(35.3)$ & $26(18.4)$ & & $49(32.5)$ & $13(14.1)$ & \\
\hline Hometown & & & 0.798 & & & 0.820 \\
\hline Songkhla & $21(20.4)$ & $31(22.1)$ & & $35(23.0)$ & $17(18.7)$ & \\
\hline 3 southern border provinces & $35(34.0)$ & $54(38.6)$ & & $55(36.2)$ & $34(37.4)$ & \\
\hline Other southern provinces & $33(32.0)$ & $38(27.1)$ & & $42(27.6)$ & 29 (31.9) & \\
\hline Other provinces & $14(13.6)$ & $17(12.1)$ & & $20(13.2)$ & $11(12.1)$ & \\
\hline Religion & & & 0.217 & & & 0.515 \\
\hline Buddhism & $78(75.7)$ & $117(83.0)$ & & 119 (78.3) & $76(82.6)$ & \\
\hline Islam/Christianity & $25(24.3)$ & $24(17.0)$ & & $33(21.7)$ & $16(17.4)$ & \\
\hline Marital status & & & 0.005 & & & $<0.001$ \\
\hline Single/divorced/widow & $42(41.2)$ & $83(60.1)$ & & $61(40.7)$ & $64(71.1)$ & \\
\hline Married/couple & $60(58.8)$ & $55(39.9)$ & & $89(59.3)$ & $26(28.9)$ & \\
\hline GPA & & & $<0.001$ & & & 0.002 \\
\hline$<3.0$ & $37(40.2)$ & $22(17.1)$ & & $46(34.3)$ & $13(14.9)$ & \\
\hline $3.0-4.0$ & $55(59.8)$ & 107 (82.9) & & $88(65.7)$ & $74(85.1)$ & \\
\hline Duration of work (year) & & & 0.003 & & & $<0.001$ \\
\hline $0-4$ & $15(14.9)$ & $48(34.3)$ & & $19(12.8)$ & $44(47.8)$ & \\
\hline $5-10$ & $28(27.7)$ & $31(22.1)$ & & $42(28.2)$ & 17 (18.5) & \\
\hline$>10$ & $58(57.4)$ & $61(43.6)$ & & 88 (59.1) & 31 (33.7) & \\
\hline
\end{tabular}


Table 5 (continued)

\begin{tabular}{|c|c|c|c|c|c|c|}
\hline \multirow[b]{2}{*}{$\begin{array}{l}\text { Demographic } \\
\text { characteristics }\end{array}$} & \multicolumn{2}{|c|}{ Emotional exhaustion } & \multirow{2}{*}{$\begin{array}{l}\text { Chi- } \\
\text { squared } \\
\text { P-value }\end{array}$} & \multicolumn{2}{|c|}{ Depersonalization } & \multirow{2}{*}{$\begin{array}{l}\text { Chi- } \\
\text { squared } \\
\text { P-value }\end{array}$} \\
\hline & $\begin{array}{l}\text { Low }(\%) \\
(n=103)\end{array}$ & $\begin{array}{l}\text { Moderate/ } \\
\text { high (\%) } \\
(n=141)\end{array}$ & & $\begin{array}{l}\text { Low (\%) } \\
(n=152)\end{array}$ & $\begin{array}{l}\text { Moderate/ } \\
\text { high (\%) } \\
(\mathrm{n}=92)\end{array}$ & \\
\hline $\begin{array}{l}\text { Duration of working at second/tertiary care } \\
\text { hospital (year) }\end{array}$ & & & 0.002 & & & $<0.001$ \\
\hline $0-4$ & $40(39.6)$ & $75(53.6)$ & & $56(37.6)$ & $59(64.1)$ & \\
\hline $5-10$ & $21(20.8)$ & $38(27.1)$ & & $40(26.8)$ & $19(20.7)$ & \\
\hline$>10$ & $40(39.6)$ & $27(19.3)$ & & $53(35.6)$ & $14(15.2)$ & \\
\hline Specialty & & & $<0.001$ & & & $<0.001$ \\
\hline Major & $67(65.0)$ & $54(38.3)$ & & $90(59.2)$ & $31(33.7)$ & \\
\hline Minor & $36(35.0)$ & $87(61.7)$ & & $62(40.8)$ & $61(66.3)$ & \\
\hline Work hour (per week) & & & $<0.001$ & & & $<0.001$ \\
\hline$\leq 40$ & $45(46.4)$ & $29(22.3)$ & & $61(42.7)$ & $13(15.5)$ & \\
\hline $41-60$ & $31(32.0)$ & $31(23.8)$ & & $39(27.3)$ & $23(27.4)$ & \\
\hline $61-80$ & $8(8.2)$ & 28 (21.5) & & $15(10.5)$ & $21(25.0)$ & \\
\hline$>80$ & $13(13.4)$ & $42(32.3)$ & & $28(19.6)$ & $27(32.1)$ & \\
\hline Perceived quality of resting or sleeping & & & $<0.001$ & & & $<0.001$ \\
\hline Adequate & $78(76.5)$ & $41(30.1)$ & & $91(60.3)$ & $28(32.2)$ & \\
\hline Not adequate & $24(23.5)$ & $95(69.9)$ & & $60(39.7)$ & $59(67.8)$ & \\
\hline Perceived work stress & & & $<0.001$ & & & 0.002 \\
\hline No & 27 (26.2) & $3(2.2)$ & & $27(17.8)$ & $3(3.3)$ & \\
\hline Yes & $76(73.8)$ & $136(97.8)$ & & $125(82.2)$ & $87(96.7)$ & \\
\hline Family relationship & & & 0.381 & & & 0.023 \\
\hline Excellent & $45(43.7)$ & $53(38.1)$ & & $63(41.4)$ & $35(38.9)$ & \\
\hline Good & $50(48.5)$ & $68(48.9)$ & & $79(52.0)$ & $39(43.3)$ & \\
\hline Fair & $8(7.8)$ & $18(12.9)$ & & $10(6.6)$ & $16(17.8)$ & \\
\hline
\end{tabular}

GPA=grade point average 


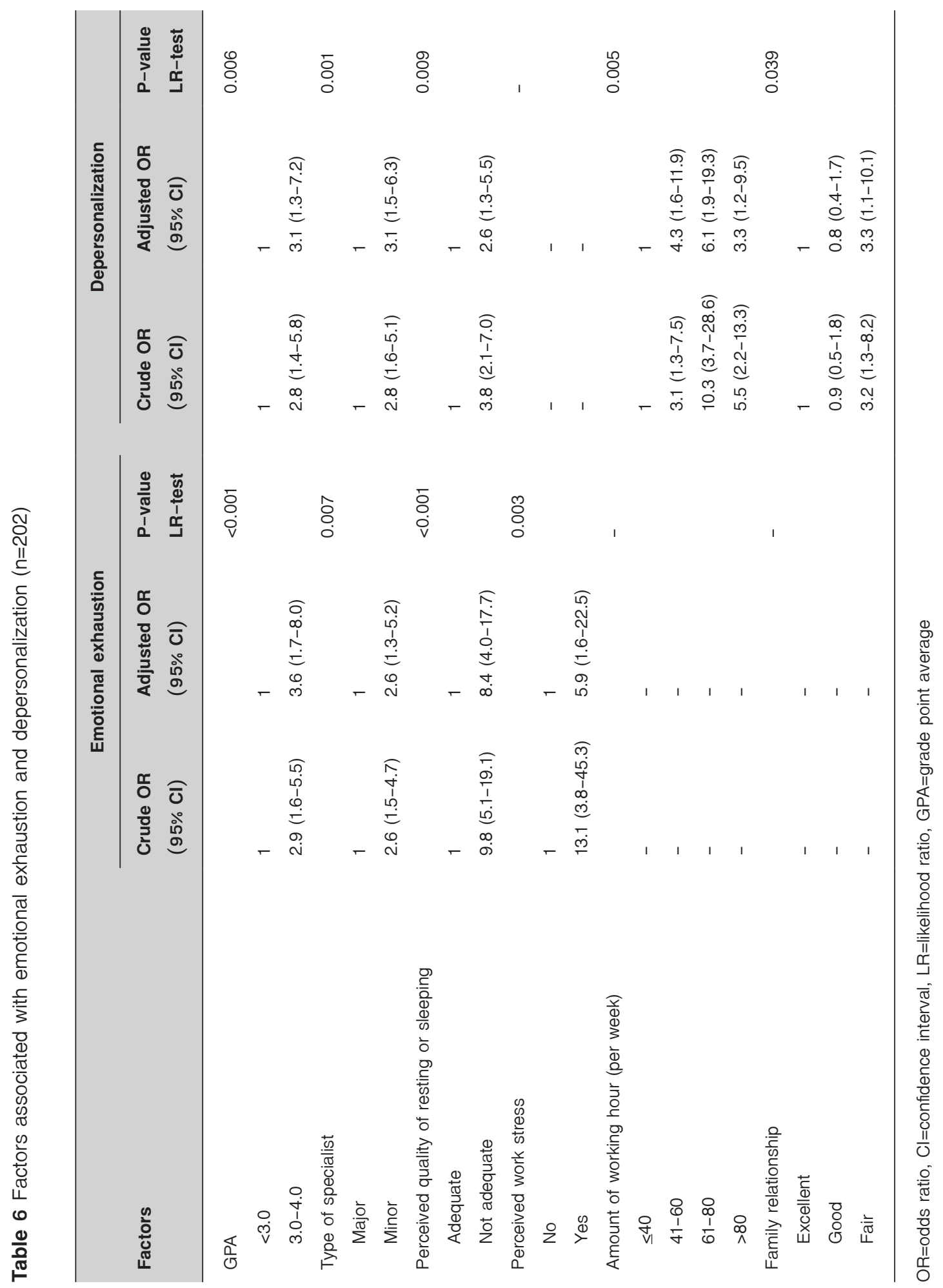




\section{Discussion}

To our knowledge within this decade, this study is the first study of BS among non-specific physicians in Thailand. The results of the study would be helpful when applied to the current health system, because it shows a prevalence of $99.6 \%$ BS, among Thai medical doctors. This being very high, so this data supports that reform in the National Health Service in Thailand is needed in order to improve the quality of life of physicians, as it seems to be urgently neccessary. ${ }^{17}$

According to this survey, there was a high to moderate burnout level of EE among Thai physicians $(57.5 \%)$, but only a few of them neglected or mistreated their patients. Most of them still indicated that they were still very capable of doing their jobs efficiently. The data seems to be not too different from a previous study in Switzerland, with most of the Swiss cancer doctors also suffering from burnout $(80.0 \%)$, which was demonstrated in the section of DP. ${ }^{18}$ The reasons of these outcomes may be the nature of people who choose to be medical doctors themselves. Another possible cause may be the influence from medical training programs and professionalism curriculums of respective medical schools, which mainly focuses on "patients". Although the doctors feel too tried, physicians couldn't abandon or neglect their patients. That means the medical training programs sometimes overlooks the physician's personal quality of life. For long term recognition, the effectiveness of patients' care and safety, by Thai physicians, who are burntout should be made aware of, as a high cumulative GPA appeared as a factor to increase the risk of burnout syndrome in this study. Some reasons for these result may be; a sense of unsuccessful, inadequate, or being failed due to limited resource. Thus, medical training curriculums should not only focus on how effective medical students do in class rooms, but be more about; humanistic and embracement, self-compassionate, coping skills of EE and stress management. ${ }^{19}$

Regarding the associated factors of BS, the data from this survey, concerning workload (>40 hours/week), was associated to the risk of DP section. Whereas, the previous study found workload (>50 hours/week) was significantly associated with an increased risk of BS. The survey showed that the practitioners had a 2 times higher risk for EE, and 2.7 times higher risk for DP. However, the mean work-hour per week of Thai doctors was 63.0 hours, with a fixed income, this number would be considered as illegal in some countries, but not in Thailand. ${ }^{20}$ Even though it seems to be not related to the same parts of BS, an overloaded work-hour, per week, were definitely associated to BS among physicians, and it is therefore, logically related to others associated factors that were found, such as: stress from work and the perception of sleep/rest quality. Good family relationships seemed to be a protective factor, which appeared to be practical, as most of them pointed out that they chose their workplaces nearby home. Minor ward specialists showed a higher score of BS than major specialists. One reason of these outcomes, among minor specialists, may be the results of unprepared life-style for the work load, after residency training. Even though their wards were called "minor”, it didn't mean they had a lower work load than those in a "major" ward, due to the nonproportion ratio of doctors and patients. Thus, their jobs discorded from their life style. For these reasons, policy makers and stake-holders of health-public in Thailand should beaware of health-cover prouder work loads and work-hour estimations, as they may be significant keys for quality of life, for both health care providers, and inevitably Thai patients. ${ }^{21}$ 


\section{Limitation}

This study was designed to be cross-sectional, and used self-reporting for assessment. Therefore, the data could not be used for summing up as to what the cause and effects were for BS, among Thai medical doctors in lower, southern Thailand. In addition, the study was quantitative, and the sample size was limited to only medical doctors in lower, southern Thailand. Thus, it is too soon to generalize nation-wide. Hence, further studies on this topic, should use a more qualitative method, and cover more areas within Thailand, in so saving a multicenter study should be conducted.

\section{Conclusion}

Almost all medical doctors, who worked at either secondary or tertiary-care hospitals, in the lower, southern areas of Thailand suffered from burnout, only 1 physician did not. No difference was found between those who work in the restive areas and non-restive areas of Thailand's southern insurgency areas. The factors associated to BS are; work hours per week, GPA, type of specialty, perception of sleeping/rest quality, perception of having stress from work and family relationships.

\section{Acknowledgement}

This research was fully granted by the Faculty of Medicine, Prince of Songkla University, Thailand. The authors feel very grateful for data analyzing by; Mrs. Nisan Werachattawan and Ms. Kruewan Jongborwanwiwat. Moreover, we would like show our appreciation for data collection from every single hospital, which participated in this study.

\section{References}

1. Freudenberger HJ. Staff burn-out. J Soc Issues 1974;30:15965.
2. Garcia-Arroyo JM, Dominguez-Lopez ML. Subjective aspects of burnout syndrome in the medical profession. PSYCH 2014;5:2064-72.

3. Maslach C, Jackson S. Burnout in health professions: a social psychological analysis. In: Sanders G, Suls J, editors. Social psychology of health and illness. New Jersey: Lawrence Erlbaum; 1982;p.227-51.

4. Krakowski AJ. Stress and the practice of medicine-the myth and reality. J Psychosom Res 1982;26:91-8.

5. Cherniss C. Long-term consequences of burnout: an exploration study. J Organ Behav 1992;13:1-11.

6. Leiter MP. Coping patterns as predictors of burnout: the function of control and escaist coping patterns. J Organ Behav 1991;12:123-44.

7. Greenglass ER, Burke RJ, Konarski R. Component of burnout, resources and gender-related differences. J Appl Soc Psychol 1998;28:1088-106.

8. Aiken LH, Clarke SP, Sloane DM, Sochalski J, Silber JH. Hospital nurse staffing and patient mortality, nurse burnout and job dissatisfaction. JAMA 2002;288:1987-93.

9. PPTVHD 36. Medical information as at 31 December 2015 [homepage on the Internet]. Bangkok: PPTVHD 36; 2015 [cited 2017 Jun 6]. Available from: https://www.pptvhd36.com/ news/hot issue/18849

10. The Medical Council of Thailand. Medical statistic [homepage on the Internet]. Nonthaburi: The Medical Council of Thailand; 2017 [cited 2017 Jun 6]. Available from: http://www.tmc.or.th/ statistics.php

11. Lerthattasilp T. Burnout among psychiatrists in Thailand: National survey. J Psychiatr Assoc Thailand 2011;56:437-48.

12. Charoenwong S, Kongsuwan V, Taogani M. Stress and psychological self-care behaviors of the people in the unrest area of Narathiwat Province, Thailand. Bangkok: Mental Health in the City; 2007.

13. Ministry of Public Health, Thailand. $12^{\text {nd }}$ health region's personnel information [homepage on the Internet]. Nonthaburi: The Ministry; 2017 [cited 2017 Aug 5]. Available from: http:// www.sasuk12.com/pdf/CHRO_27Oct2016.pdf

14. Yamane T. Statistics; an introductory analysis. $2^{\text {nd }}$ ed. New York: Harper and Row; 1967.

15. Maslash C, Jackson SE. The measurement of experienced burnout. J Occup Behav 1981;2:99-113. 
16. Maslach C, Schaufeli WB, Leiter MP. Job burnout. Annu Rev Psychol 2001;52:397-422.

17. Jareonsettasin T. Health systems reform in England history of NHS in England [homepage on the Internet]. Bangkok: Health Systems Research Institute (HSRI); 2001 [cited 2018 May 15]. Available from: http://kb.hsri.or.th/dspace/handle/11228/1744? locale-attribute=th

18. Arigoni F, Bovier PA, Mermillod B, Waltz P, Sappino AP. Prevalence of burnout among Swiss cancer clinicians, paediatricians and general practitioners: who are most at risk? Support Care Cancer 2009;17:75-81.
19. Shapiro SL, Shapiro DE, Schwartz GE. Stress management in medical education: a review of the literature. Acad Med 2000; 75:748-59.

20. United States Department of Labor. Work hours [homepage on the Internet]. Washington: United States Department of Labor; 2018 [cited 2018 May 22]. Available from: https://www.dol.gov/ general/topic/workhours

21. Staiger DO, Auerbach DI, Buerhaus PI. Trends in the work hours of physicians in the United States. JAMA 2010;303:747-53. 